Reviu Akuntansi dan Bisnis Indonesia, Vol. 3 No. 2, Hlm: 206-219, Desember 2019

Website: http://journal.umy.ac.id/index.php/rab

\title{
Pengaruh Persistensi Laba, Book Tax Differences, Investment Opportunity Set dan Struktur Modal Terhadap Kualitas Laba dengan Konservatisme Akuntansi Sebagai Variabel Moderasi (Studi Empiris pada Perusahaan Jasa yang Terdaftar di BEI Periode 2015- 2017)
}

Fathin Ulfatul Ashma *; Evi Rahmawati

Program Studi Akuntansi Universitas Muhammadiyah Yogyakarta

I N F O A R T I K E L

Kata Kunci:

Earnings Quality, Earnings

Persistence, Investment

Oppotunity Set, Book tax

differences, Capital

Structure, Accounting

Conservatism.

Jenis Artikel:

Penelitian Empiris

Correspondence:

fathinulfa@yahoo.com

\begin{abstract}
A B S T R A K
This research aims to examine the Effect of Earnings Persistence, Investment Oppotunity Set, Book tax differences and Capital Structure on Earnings Quality with Accounting Conservatism as Moderating Variable. The population in this research are service companies listed in Indonesia Stock Exchange for the period 2015-2017. The data used in this study are secondary data in the form of quantitative data from the financial statements of service companies listed on the Indonesia Stock Exchange (IDX) in 2015-2017. In this research the method used for sampling is using the purposive sampling method and obtained a sample of 268 samples. Data obtained from the Indonesia Stock Exchange (IDX) and the website www.idx.co.id, the data analyzed in this study are processed from annual reports and company financial statements. Based on the analysis that has been done, the results show that the earnings persistence and Investment Opportunity Set does not affect the quality of earnings. Book Tax Differences has a negative effect on earnings quality. Capital structure has a positive effect on earnings quality. Book tax differences has a effect on earnings quality with accounting conservatism as a moderating variable.
\end{abstract}

(C) 2019 RAB. Published by Universitas Muhammadiyah Yogyakarta

\section{PENDAHULUAN}

Perusahaan memiliki komponen yang sangat penting dalam memprediksi kinerja keuangan yang akan terjadi dimasa yang akan datang. Komponen tersebut adalah laporan keuangan. Laporan keuangan merupakan suatu catatan mengenai informasi keuangan perusahaan pada suatu periode akuntansi yang dapat digunakan untuk menilai bagaimana kinerja perusahaan dan diharapkan dapat memberikan informasi kepada semua pihak yang berkepentingan baik pihak internal maupun pihak eksternal perusahaan. Informasi dalam laporan keuangan sangat dibutuhkan oleh investor untuk meminimalkan kesalahan mereka dalam pengambilan keputusan investasi. Laporan keuangan memiliki informasi laba yang menjadi salah satu bagian terpenting dan menjadi hal yang paling diperhatikan oleh berbagai pihak eksternal seperti investor karena laba menjadi salah satu komponen yang dapat dijadikan sebagai alat untuk menilai kinerja perusahaan dalam pengambilan keputusan. Melalui informasi laba, investor dapat mengetahui bagaimana kondisi sumber daya 
perusahaan saat ini karena investor akan melakukan penilaian terhadap perusahaan agar terhindar dari kesalahan dalam melakukan investasi. Pentingnya informasi laba menjadi motivasi bagi perusahaan untuk terus berupaya meningkatkan labanya karena pada dasarnya pihak eksternal cenderung memilih untuk melakukan investasi pada perusahaan yang memiliki tingkat laba yang tinggi dengan tujuan untuk memperoleh keuntungan sesuai yang diharapkan.

Namun, akhir-akhir ini banyak dari manajemen perusahaan yang melakukan berbagai tindakan tidak sehat. Manajemen perusahaan yang merasa kondisi perusahaanya sedang menurun akan berupaya melakukan berbagai cara untuk meminimalisir kondisi tersebut, salah satu hal yang mungkin yang dilakukan perusahaan adalah melakukan rekayasa atau manipulasi informasi laba dengan melaporkan laba yang tidak sesuai dengan kondisi perusahaan yang sebenarnya. Adanya tindakan kecurangan manajemen dalam melaporkan laba yang tidak sesuai dengan kondisi perusahaan yang sebenarnya menyebabkan laba yang dihasilkan diragukan kualitasnya. Jika fenomena seperti ini terus terjadi, maka akan membuat banyak pihak pengguna laporan keuangan merasa dirugikan karena setiap pihak mempunyai kepentingan tersendiri atas informasi laba tersebut.

\section{TINJAUAN LITERATUR DAN PERUMUSAN HIPOTESIS}

Spence (2009) mendefinisikan sinyal adalah sesuatu yang dapat memberikan informasi dan jika hal-hal menyangkut pemberi sinyal tidak terlihat bagi penerima sinyal, maka informasi tersebut dapat diubah. Sinyal yang diberikan perusahaan dapat berupa informasi tentang kinerja mereka sebagai upaya untuk meningkatkan keuntungan dan nilai perusahaan. Teori Agensi merupakan teori yang meyatakan hubungan antara principal dan agen dalam bentuk kerjasama. Yang dimaksud sebagai principal disini adalah investor yang merupakan pihak yang memberi wewenang dan yang dimaksud sebagai agen adalah manajer yang merupakan pihak yang menerima wewenang. Teori keagenan menjelaskan mengenai pemisahan kepemilikan antara pihak eksternal dengan manajemen perusahaan (Jensen dan Meckling, 1976).

Kualitas laba merupakan pengukuran yang digunakan oleh perusahaan untuk membandingkan apakah yang telah direncanakan sebelumnya sudah sesuai dengan laba yang dihasilkan saat ini atau belum karena laba yang berkualitas mengindikasikan kinerja keuangan dari perusahaan tersebut. Laba yang berkualitas adalah laba yang mampu memberikan informasi mengenai kinerja keuangan perusahaan sesuai dengan realitas yang ada tanpa adanya rekayasa atau manipulasi data. Apabila laba yang dihasilkan perusahaan terbukti berkualitas, maka pihak eksternal tidak akan segan untuk memberikan dananya untuk diinvestasikan pada perusahaan tersebut.

Hanlon (2005) menyatakan bahwa persistensi laba merupakan pengukuran yang dilakukan untuk menjelaskan mengenai kemampuan perusahaan untuk tetap mempetahankan laba yang diperolehnya saat ini sampai satu periode yang akan datang apabila komponen akrual dan aliran kas dapat bepengaruh terhadap laba sebelum pajak di masa mendatang, maka laba tersebut dapat dikatakan persisten. Laba perusahaan yang mampu bertahan secara stabil dari tahun ke tahun mencerminkan laba yang berkualitas. perusahaan tidak menyesatkan pengguna informasi, karena laba perusahaan tersebut stabil.

Book tax differences merupakan perbedaan antara laba komersial. dan laba fiskal Laba komersial adalah perhitungan laba berdasarkan Standar Akuntansi Keuangan yang berisi informasi keuangan selama periode akuntansi yang dicatat sebelum dikurang dengan beban pajak sedangkan laba fiskal adalah perhitungan laba berdasarkan peraturan perpajakan yang telah ditetapkan dan menjadi dasar penghitungan pajak penghasilan. Book tax differences disebabkan oleh perbedaan permanen dan perbedaan temporer. Perbedaan antara laba yang fiskal dan laba komersial ditandai adanya koreksi fiskal atas laba akuntansi.

Investment opportunity set merupakan gambaran dari besarnya kesempatan investasi bagi suatu perusahaan, namun kesempatan tersebut bergantung pada pengeluaran perusahaan untuk kepentingan dimasa mendatang. Investasi merupakan salah satu cara perusahaan untuk dapat 
mengembangkan perusahaannya, namun banyak dari perusahaan yang tidak dapat memanfaatkan kesempatan tersebut. Perusahaan yang memiliki kesempatan bertumbuh yang baik akan memberikan pengaruh yang baik bagi investor untuk berinvestasi pada perusahaan tersebut dengan tujuan untuk memperoleh return yang tinggi. Investment opportunity set merupakan dasar untuk menentukan bagaimana pertumbuhan perusahaan dimasa mendatang karena cara pandang manajer, pemilik, investor dan kreditor terhadap perusahaan dapat dipengaruhi oleh IOS pada perusahaan (Warianto dan Rusiti, 2014).

Struktur modal menunjukkan bagaimana cara perusahaan memadukan antara jumlah hutang dengan jumlah aset yang dimiliki oleh perusahaan sehingga ditemukan komposisi yang baik bagi perusahaan. Modal bisa diartikan sebagai suatu komponen dana jangka panjang yang dimiliki oleh perusahaan. Struktur modal diproksikan dengan leverage. Leverage merupakan penggunaan biaya yang memiliki beban tetap dengan tujuan untuk memperoleh tambahan keuntungan yang tinggi bagi perusahaan sehingga akan meningkatkan keuntungan.

Konservatisme akuntansi merupakan metode yang dilakukan perusahaan untuk mengantisipasi adanya badnews dengan mengurangi laba (Basu, 2009). Keterkaitan antara metode konservatisme akuntansi dengan prinsip akuntansi adalah adanya ketentuan dimana akuntansi mengakui kerugian yang mengkin terjadi dan tidak terlalu cepat mengakui laba yang mungkin terjadi di masa mendatang. Prinsip konservatisme akuntansi diterapkan dalam perusahaan untuk menghindari sikap optimisme yang terlalu berlebihan, untuk itu perusahaan akan bersikap hati-hati dalam melaporkan keuangannya. Dalam prinsip konservatisme akuntansi, perusahaan diharuskan untuk mengakui rugi yang kemungkinan dapat terjadi, namun tidak mengakui laba sebelum terjadi.

\section{Pengaruh Persistensi Laba terhadap Kualitas Laba}

Persistensi laba merupakan indikator yang menjelaskan mengenai kemampuan perusahaan dalam mempertahankan laba dari tahun ke tahun agar tetap stabil. Perusahaan dengan laba yang persisten akan menarik minat investor untuk melakukan investasi pada perusahaan tersebut karena menurut investor apabila perusahaan memiliki laba yang persisten, maka perusahaan tersebut dapat menjaga kestabilan kondisi keuangannya. Teori keagenan menjelaskan bahwa di dalam hubungan antara manajemen dan investor terdapat keinginan dari manajemen untuk mempertahankan labanya agar tetap baik dimata investor. Salah satu cara untuk tetap mempertahankan respon baik investor terhadap perusahaan adalah dengan melihat persistensi laba. Para pihak eksternal cenderung memilih perusahaan yang memiliki laba yang persisten karena laba yang kurang persisten akan menyebabkan pihak eksternal mengalami masalah ketidaktepatan dalam pengambilan keputusan investasi.

Mulyani dkk (2007) menyatakan bahwa persistensi laba berpengaruh positif terhadap kualitas laba. Hal ini dikarenakan investor akan tertarik pada perusahaan yang mampu mempertahankan labanya dengan stabil dari tahun ke tahun, respon investor tercermin dari tingginya kualitas laba karena kondisi perusahaan tersebut yang dianggap mampu menjaga kondisi keuangannya agar tetap stabil. Penelitian ini sejalan dengan penelitian Ambarwati (2008) dan Malahayati dkk (2015). Berdasarkan uraian diatas peneliti menurunkan hipotesis sebagai berikut:

\section{$\boldsymbol{H}_{I} \quad$ : Persistensi laba berpengaruh positif terhadap kualitas laba}

Pengaruh Book tax differences terhadap Kualitas Laba

Perbedaan penyajian laporan keuangan dalam perusahaan timbul karena adanya perbedaan antara pelaporan menggunakan peraturan perpajakan dan menurut standar akuntansi. Akuntansi keuangan memiliki tujuan yang bebeda dengan akuntansi perpajakan. Book tax tax differences tidak hanya disebabkan oleh perbedaan permanen dan temporer tetapi dapat pula disebabkan oleh tiga hal yaitu adanya manajemen laba yang dilakukan perusahaan, strategi perencanaan pajak (tax planning) perusahaan dan perbedaan yang terjadi karena adanya perbedaan perlakuan atas 
pendapatan dan beban menurut akuntansi dan menurut pajak (Tampubolon dan Kartikaningdyah, 2016). Timbulnya beban pajak tangguhan disebabkan oleh perbedaan temporer antara laba akuntansi dan laba fiskal. Book tax differences dapat mewakili keleluasaan manajemen dalam proses akrual dimana terdapat sedikit kebebasan akuntansi yang diperbolehkan dalam pengukuran penghasilan kena pajak sehingga book tax differences dapat memberikan informasi mengenai manajemen laba dalam proses akrual (Wijayanti, 2006). Adanya fleksibelitas dalam penyusunan laporan keuangan dapat dimanfaatkan oleh manajemen untuk melakukan manajemen laba (Amelia dan Yudianto, 2016).

Teori keagenan menjelaskan bahwa terdapat pemisahan antara pihak manajemen dan investor yang dapat mengakibatkan konflik keagenan dan dapat memengaruhi kualitas laba. Konflik keagenan dapat menyebabkan timbulnya sifat manajemen untuk melaporkan laba secara oportunis untuk memaksimalkan keuntungan pribadinya. Manajemen akan memilih metode yang dapat sesuai dengan motivasinya untuk memperoleh laba yang tinggi, hal tersebut dapat memengaruhi kualitas laba yang dihasilkan. Semakin tinggi book tax differences maka semakin rendah kualitas laba yang dihasilkan karena anggapan bahwa perusahaan tersebut melakukan manajemen laba untuk meminimalisir kerugian. Penelitian ini sejalan dengan penelitian Amelia dan Yudianto (2016) yang menyatakan bahwa book tax differences berpengaruh negatif terhadap kualitas laba. Berdasarkan penjelasan diatas peneliti merumuskan hipotesis sebagai berikut:

\section{$\boldsymbol{H}_{2} \quad$ : Book Tax Difference berpengaruh negatif terhadap kualitas laba}

Pegaruh Investment opportunity set terhadap kualitas laba

Investments Opportunity Set merupakan suatu investasi dimasa mendatang yang dilakukan untuk mengembangkan suatu perusahaan. Semakin besar investment opportunity set yang yang dimiliki perusahaan, maka semakin besar pula kesempatan investor untuk tertarik melakukan investasi pada perusahaan tersebut karena adanya harapan untuk memperoleh return yang lebih tinggi. Telah dijelaskan dalam teori sinyal bahwa Informasi yang diberikan oleh pihak manajemen kepada pihak eksternal akan memberikan sinyal bagi pihak eksternal dalam pengambilan keputusan. Laba yang berkualitas akan memberikan sinyal yang positif bagi para pihak eksternal. Investment opportunity set yang tinggi dinilai positif oleh investor karena mempunyai prospek keuntungan yang tinggi, sehingga banyak investor yang tertarik untuk berinvestasi pada perusahaan yang mempunyai investment opportunity set yang tinggi. Mulyani dkk (2007) menjelaskan bahwa perusahaan dengan investment opportunity set yang tinggi akan mendapatkan respon yang tinggi dari pihak eksternal karena anggapan bahwa perusahaan akan memperoleh laba yang lebih besar. Penelitian ini sejalan dengan Rachmawati dan Triatmoko (2007) serta Warianto dan Rusiti (2014) yang menyatakan bahwa investment opportunity set berpengaruh positif terhadap kualitas laba. Semakin tinggi nilai investment opportunity set yang dimiliki oleh perusahaan, maka semakin tinggi pula kualitas laba yang dihasilkan karena tingginya respon pihak eksternal terhadap perusahaan yang memiliki investment opportunity set yang tinggi. Berdasarkan uraian diatas, peneliti merumuskan hipotesis sebgaia berikut:

\section{$\boldsymbol{H}_{3} \quad$ : Investment Oppotunity Set berpengaruh negatif terhadap kualitas laba}

Pengaruh Struktur Modal terhadap kualitas laba

Struktur modal merupakan salah satu hal yang penting dalam suatu perusahaan karena awal dari jalannya suatu bisnis pada perusahaan adalah karena adanya modal. Dalam teori keagenan dijelaskan bahwa manajemen dan pihak eksternal memiliki kepentingan yang berbeda dan menyebabkan konflik keagenan. Penggunaan hutang yang tinggi akan menimbulkan konflik keagenan antara manajemen dan pihak eksternal sehingga memunculkan biaya keagenan hutang. 
Investor menginginkan standar tertentu untuk mencapai tugas yang telah diberikan kepada pihak manajemen, sedangkan manajemen juga mengharapkan pencapaian yang memuaskan. Semakin tinggi hutang yang dimiliki oleh perusahaan, maka semakin dinamis pula kondisi perusahaan tersebut. Investasi yang terus meningkat menunjukkan bahwa perusahaan tersebut mempunyai prospek keuntungan dimasa mendatang. Hasil penelitian ini sejalan dengan penelitian yang dilakukan oleh Sugiarto, dkk (2007) menyatakan bahwa semakin besar hutang suatu perusahaan maka mencerminkan laba yang berkualitas.

Menurut Dira dan Astika (2014) struktur modal berpengaruh positif terhadap kualitas laba. Hal tersebut serupa dengan pernyataan Risdawaty dan Subowo (2015) serta Septiyani dkk (2017) yang menyatakan bahwa struktur modal berpengaruh positif terhadap kualitas laba. Semakin besar leverage pada perusahaan, maka kualitas laba yang dihasilkan akan semakin tinggi, sumber dana yang berasal dari pihak internal maupun eksternal perusahaan akan memberikan manfaat bagi perusahaan dan pihak eksternal. Berdasarkam uraian diatas peneliti merumuskan hipotesis sebagai berikut:

\section{$\boldsymbol{H}_{4} \quad$ : Struktur Modal berpengaruh positif terhadap kualitas laba}

Pengaruh Book tax differences terhadap kualitas laba yang dimoderasi oleh konservatisme akuntansi

Teori keagenan menjelaskan bahwa antara manajemen dan investor terdapat keinginan dari manajemen dimana manajemen berusaha melakukan yang terbaik agar respon investor terhadap laba perusahaan tetap baik. Cara yang dapat dilakukan manajemen agar investor dapat merespon baik laba perusahaan adalah dengan metode konservatisme akuntansi. Pihak eksternal yang memiliki kepentingan dalam perusahaan akan berupaya untuk melakukan analisa terhadap laporan keuangan yang disajikan oleh perusahaan, salah satu hal yang dilihat oleh investor dan kreditor adalah metode akuntansi yang digunakan oleh manajemen. Penman dan zhang (2002) menjelaskan bahwa laba yang berkualitas dapat1diperolehlapabila pihak manajemen menerapkan prinsip konservatisme akuntansi secara konsisten. Penyebab timbulnya prinsip konservatime adalah karena adanya PSAK. Dalam PSAK prinsip konservatisme terlihat dari beragamnya pilihan metode pencatatan akuntansi sehingga menyebabkan perbedaan hasil dalam laporan. Prinsip konservatisme dapat memengaruhi hasil dari laporan keuangan (Savitri, 2016). Prinsip akuntansi yang berlaku umum (PABU) memberikan kebebasan bagi perusahaan untuk menentukan metode akuntansi apa akuntansi yang dapat digunakan. Adanya kebebasan tersebut dapat memengaruhi perilaku manajemen perusahaan dalam melakukan, mencatat dan melaporkan transaksi keuangan dalam perusahaan sehingga dapat memengaruhi kualitas laba perusahaan.

Penerapan metode konservatisme akuntansi ini akan lebih membantu book tax differences agar memiliki laba yang lebih berkualitas. Namun, sikap pesimistik manajemen dalam pelaporan laba dapat berakibat pada pelaporan laba yang rendah sehingga menyebabkan anggapan kurang baik terhadap kinerja manajemen dalam mengelola perusahaan karena tidak menghasilkan laba yang sesuai target (soraya dan Harto, 2014). En (2017) mengemukakan bahwa konservatisme melemahkan pengaruh antara Book tax differences dan kualitas laba. Berdasarkan uraian diatas peneliti merumuskan hipotesis sebagai berikut:

$\mathbf{H}_{5} \quad$ : Konservatisme Akuntansi memperlemah hubungan antara Book tax differences dan kualitas laba

\section{METODE PENELITIAN}

Objek Penelitian 
Objek atau populasi yang digunakan dalam penelitian ini adalah perusahaan jasa yang terdaftar di BEI. Sampel yang digunakan adalah seluruh perusahaan jasa yang terdaftar di Bursa Efek Indonesia (BEI) tahun 2015-2017.

Teknik Pengambilan Sampel

Metode yang digunakan untuk pengambilan sampel yaitu menggunakan metode purposive sampling yang ditentukan oleh kriteria - kriteria sesuai keinginan peneliti. Berikut ini adalah kriteria yang ditentukan untuk pemilihan sampel:

1. Perusahaan jasa yang terdaftar di Bursa Efek Indonesia tahun 2015- 2017.

2. Laporan keuangan pada perusahaan jasa yang disajikan dalam mata uang rupiah.

3. Laporan keuangan pada perusahaan jasa memiliki data yang lengkap.

Teknik Pengumpulan Data

Penelitian ini menggunakan metode dokumentasi untuk mengumpulkan data. Data yang digunakan dalam metode ini adalah data dari laporan tahunan serta laporan keuangan perusahaan jasa pada tahun 2015-2017 di web Bursa Efek Indonesia (www.idx.co.id) dengan cara mengunduh. Setelah data tersebut terkumpul, maka dilakukan pemilahan sampel berdasarkan kriteria yang telah ditetapkan.

Jenis Data

Jenis data yang digunakan dalam penelitian ini adalah data sekunder berupa data kuantitatif dari laporan keuangan perusahaan jasa yang terdftar di Bursa Efek Indonesia (BEI) tahun 20152017. Alasan penelitian ini memilih perusahaan jasa sebagai obyek penelitian adalah karena perusahaan jasa merupakan perusahaan yang sangat bekembang pesat pada saat ini, hal tersebut terlihat dari banyaknya masyarakat yang membutuhkan jasa dalam setiap aktivitasnya.

Defini Operasional dan Pengukuran Variabel Penelitian

1. Variabel Dependen.

Kualitas laba merupakan variabel dependen dalam penelitian ini. Kualitas laba dihitung dengan menggunakan model modified jones. Model Modified Jones mencoba memperbaiki model jones yang mengasumsikan bahwa semua perubahan yang terjadi dalam penjualan kredit merupakan manipulasi laba. Berikut ini langkah-langkah perhitungan model modified jones:

Mencari total akrual

$$
T A C_{a}=N I_{a}-C F O
$$

Mengestimasi koefisien dari permasamaan regresi

Menghitung nondiscretionary accruals (NDA)

$$
\frac{T A C_{a}}{A_{a}}=\alpha_{1} \frac{1}{A_{i t-1}}+\alpha_{2}\left(\frac{\Delta R E V_{i t}}{A_{i t-1}}\right)+\alpha_{3}\left(\frac{\Delta P P E_{i t}}{A_{i t-1}}\right)
$$

$$
N D A_{i t}=\propto_{1}\left(\frac{1}{A_{i t-1}}\right)+\propto_{2}\left(\frac{\Delta R E V_{i t}-\Delta R E C_{i t}}{A_{i t-1}}\right)+\propto_{3}\left(\frac{\Delta P P E_{i t}}{A_{i t-1}}\right)
$$

Menentukan nilai discretionary accrual 


$$
D A C_{t}=\left(\frac{T A C_{i t}}{A_{i t-1}}-N D A_{i t}\right)
$$

Kualitas laba merupakan nilai negatif dari nilai Discretionary Accrual

$$
E Q=D A C_{t} \times-1
$$

Keterangan :

EQ : Earnings Quality

$D A C_{t} \quad:$ Discretionary Accrual

$N D A_{i t} \quad:$ Non discretionary accrual

$T_{A C} \quad:$ Total Accrual

$\mathrm{NI}_{a} \quad:$ Net Income

CFO : Cash Flow Operating

$A_{i t-1} \quad$ : total aset pada t-1

$\triangle R E V \quad$ : pendapatan tahun t dikurangi dengan pendapatan pada tahun t-1

$\triangle R E C_{t} \quad$ : piutang pada tahun t dikurangi dengan piutang pada t-1

$P P E_{t} \quad$ : Property, plan, dan equipmnet (gross) pada tahun $\mathrm{t}$

$\propto_{1} \propto_{2} \propto_{3}$ : firm- spesific parameter

Adanya praktik manajemen laba laba dilihat melalui discrecionay accrual (DA) yang ditandai dengan nilai $\mathrm{DA}=0$. Nilai $\mathrm{DA}=0$ mengindikasikan baha perusahaan melakukan praktik perataan laba. Apabila nilai DA positif, maka perusahaan cenderung melakukan manajemen laba dengan pola menaikkan nilai laba, apabila nilai DA negatif, maka menunjukkan bahwa perusahaan cenderung melakukan manajemen laba dengan pola penurunan laba (Apriliana, 2017). Discrecionary Accrual menunjukkan tindakan opportunistik manajemen terhadap laporan keuangan. Semakin tinggi nilai discrecionary accrual menunjukkan semakin rendahnya kualitas laba.

Variabel Independen

a. Persistensi Laba

Pengukuran persistensi laba akuntansi menurut Persada dan Martani (2010) diukur didasarkan pada rumus sebagai berikut:

$$
\mathrm{PL}=\frac{\text { Laba sebelum pajak }_{\mathrm{t}-1}-\text { Laba sebelum pajak }}{\mathrm{t}}
$$

b. Book tax differences

Dalam penelitian ini book tax differences diukur menggunakan rumus hanlon yang dihitung dengan membagi beban pajak tangguhan dengan rata-rata total aset (Hanlon, 2005).

$$
\text { BTD }=\frac{\text { Beban pajak tangguhan }}{\text { Rata }- \text { rata total aset }}
$$

c. Investment opportunity set

Penggolongan petumbuhan perusahaan dimasa mendatang terkait apakah termasuk dalam perusahaan yang bertumbuh atau tidak ditentukan oleh Investment opportunity set. Penelitian ini 
menggunakan proksi Market Value to Book Value of Assets Ratio (MVBVA) sama seperti dalam penelitian Rachmawati dan Triatmoko (2007).

$$
\operatorname{MVBVA} \frac{\mathrm{TA}-\mathrm{TE}+(\mathrm{JSB} \times \mathrm{HPS})}{\mathrm{TA}}
$$

Keterangan:

MVBVA : Market Value to Book Value of Assets Ratio

TA : Total Aset

TE : Total Ekuitas

JSB : Jumlah Saham Beredar

HPS : Harga Penutupan Saham

d. Struktur Modal

Struktur modal merupakan suatu variabel yang digunakan oleh perusahaan untuk mengukur sebesar apa aset perusahaan yang dianggarkan oleh hutang perusahaan. Struktur modal diukur dengan leverage karena untuk menghitung besarnya aset perusahaan yang dikeluarkan dengan hutang perusahaan. Proksi dari struktur modal menurut Anjelica dan Prasetyawan (2014) adalah dengan Debt to Equity Ratio (DER).

3. Variabel Moderasi

$$
\text { Leverage } \frac{\text { Total Hutang }}{\text { Total Aset }}
$$

Dalam penelitian ini variabel moderasi yang digunakan adalah konservatisme akuntansi. Menurut En (2017) pengukuran tingkat konservatisme akuntansi yang sering digunakan adalah model Givoly and Hayn sebagai berikut:

$$
\mathrm{KNSV}=\frac{\text { Net Profit }- \text { Operating Cash Flow }- \text { Depreciation }}{\text { Total Asset }} \mathrm{x}-1
$$

Persamaan Regresi

$$
\mathrm{KL}=\alpha+\beta_{1} \mathrm{PL}+\beta_{2} \mathrm{BTD}+\beta_{3} \mathrm{IOS}+\beta_{4} \mathrm{SM}+\beta_{5} \mathrm{KA}+\beta_{6} \mathrm{BTD} * \mathrm{KA}+\mathrm{e}
$$

Keterangan:

$\begin{array}{ll}\alpha & : \text { Konstanta } \\ K L & : \text { Kualitas Laba } \\ B T D & : \text { Book Tax Differences } \\ P L & : \text { Persistensi Laba } \\ \text { IOS } & : \text { Investment Opportunity Set } \\ S M & : \text { Struktur Modal } \\ K \mathrm{~A} & : \text { Konservatisme Akuntansi } \\ B T D * K \mathrm{~A} & : \text { Interaksi antara Book tax differences dan Konservatisme Akuntansi } \\ \beta_{1} \beta_{2} \beta_{3} \beta_{4} \beta_{5} \beta_{6} & : \text { Koefisien regresi } \\ e & : \text { error }\end{array}$


Metode Analisis Data

\section{Analisis Statistik Deskriptif}

Analisis statistik deskriptif memiliki tujuan untuk mendeskripsikan suatu data agar mudah dipahami. Analisis ini dapat dipakai untuk melihat nilai minimal, maksimal, rata-rata (mean), serta simpangan baku (standar deviasi) dari variabel penelitian yang diteliti (Nazaruddin dan Basuki, 2017).

\section{Uji Asumsi Klasik}

Pengujian asumsi klasik yang dilakukan dalam penelitian ini antara lain:

a. Uji Normalitas

Uji normalitas digunakan untuk menguji adanya variabel pengganggu atau tingkat residual memiliki distribusi normal dalam model regresi (Ghozali, 2011). Pengujian ini menggunakan KolmogorovSmirnov (KS), yaitu dengan menggunakan kriteria jika sig $>\alpha \quad(0,05)$ maka residual dapat dikatakan berdistribusi normal, sebaliknya jika sig $<\alpha(0,05)$ maka residual dapat dikatakan tidak berdistribusi normal.

\section{b. Uji Multikolinearitas}

Uji multikolinieritas digunakan dengan tujuan untuk menguji apakah terdapat korelasi antar variabel bebas di dalam model regresi. Jika nilai Variance Inflation Factors (VIF) $<10$ serta nilai tolerance $>0,1$ maka dikatakan bahwa kedua persamaan regresi tidak terdapat masalah multikolinieritas, sebaliknya jika nilai Variance Inflation Factors (VIF) > 10 serta nilai tolerance $<0,1$ maka dikatakan bahwa kedua persamaan regresi terdapat masalah multikolinieritas

\section{c. Uji Heteroskedestisitas}

Uji ini dilakukan untuk mengetahui adanya penyimpangan syarat-syarat asumsi klasik pada model regresi dimana syarat yang harus dipenuhi model regresi adalah tidak adanya masalah heterokedastisitas (Nazaruddin dan Basuki, 2017). Jika nilai signifikansi $>\alpha(0,05)$ maka tidak terjadi masalah heteroskedastisitas, sebaliknya jika nilai signifikansi $<\alpha(0,05)$ maka tidak terjadi masalah heteroskedastisitas.

\section{d. Uji Autokorelasi}

Pengujian ini digunakan untuk melihat apakah terdapat penyimpangan asumsi klasik autokorelasi. Persamaan regresi yang tidak terdapat masalah autokorelasi karena jika terdapat masalah autokorelasi, maka persamaan regresi tersebut tidak layak untuk dijadikan prediksi (Sunyoto 2013). Menurut Nazaruddin dan Basuki (2017) metode yang sering digunakan dalam uji autokorelasi adalah dengan melihat uji Durbin Watson dengan ketentuan sebagai berikut:

1. Jika d lebih kecil dari dL atau kebih besar dari (4-dL), maka hipotesis nol ditolak, yang berarti terdapat autokorelasi

2. Jika d terletak antara dU dan (4-dU), maka hipotesis nol diterima dan tidak terdapat autokorelasi

3. Jika d terletak antara dL dan dU atau diantara (4-dU) dan (4-dL), amaka tidak menghasilkan kesimpulan yang pasti 
Uji Hipotesis dan Analisis Data

\section{Uji Koefisien Determinasi (Uji Adjusted $\mathrm{R}^{2}$ )}

Uji koefisien determinasi digunakan untuk mengetahui pengaruh antara variabel bebas (independen) terhadap variabel terikat (dependen). Presentase total variance dapat ditentukan dengan uji koefisien determinan $\left(\mathbf{R}^{2}\right)$. Pengujian ini dilakukan dengan melihat nilai koefisien determinasi R2. Nilai yang kecil menunjukkan kemampuan vaiabel-variabel independen dalam menjelaskan variabel dependen sangat kecil. Nilai yang mendekati satu berarti variabel-variabel independen memberikan hampir semua informasi yang dibutuhkan untuk memprediksi variasi variabel dependen (Nazaruddin dan Basuki, 2017).

\section{Uji Parsial (Uji Statistik t)}

Uji Statistik t bertujuan untuk melihat apakah pengaruh setiap variabel independen terhadap variabel dependen parsial yang ditunjukkan pada tabel koefisien (Nazaruddin dan Basuki, 2017). Pengujian ini menggunakan pengamatan nilai signifikan t pada tingkat $=0,05$ dengan ketentuan apabila nilai sig $>\alpha$ dan atau koefisien regresi berlawanan arah dengan hipotesis penelitian, maka hipotesis tidak dapat diterima atau menunjukkan secara parsial variabel independen tidak berpengaruh terhadap variabel dependen, sebaliknya apabila nilai sig $<\alpha$ dan koefisien regresi searah dengan hipotesis penelitian, maka hipotesis dapat diterima atau menunjukkan bahwa secara parsial variabel independen berpengaruh terhadap variabel dependen.

\section{Uji Signifikansi Simultan (Uji Statistik Nilai F)}

Uji Statistik Nilai $\mathbf{F}$ bertujuan untuk menguji apakah seluruh variabel bebas (independen) berpengaruh secara bersama-sama terhadap variabel terikat (variabel dependen) yang ditunjukkan dalam Tabel ANOVA (Nazaruddin dan Basuki, 2017). Pengujian ini menggunakan pengamatan nilai signifikan pada tingkat $\alpha$. Dalam penelitian ini menggunakan tingkat $\alpha$ sebesar $5 \%$ dengan ketentuan jika nilai signifikan >0,05, maka variabel independen secara simultan tidak berpengaruh terhadap variabel dependen, jika nilai signifikan $<0,05$, maka variabel independen secara simultan berpengaruh terhadap variabel dependen.

\section{Analisis Regresi Berganda}

Dalam penelitian ini, analisis regresi berganda digunakan untuk melihat apakah variabel moderasi dapat memoderasi hubungan antara variabel independen dengan variabel dependen. Analisis ini dilakukan dengan melakukan perbandingan antara nilai Adjusted $\mathbf{R}^{2}$ dari hasil regresi persamaan pertama dengan hasil regresi pada persamaan kedua. Apabila nilai Adjusted $\mathbf{R}^{2}$ pada hasil regresi persamaan pertama > nilai Adjusted $\mathbf{R}^{2}$ pada hasil regresi persamaan kedua, maka variabel yang dihipotesiskan sebagai variabel moderasi tidak dapat digunakan sebagai variabel moderasi. Namun, apabila nilai Adjusted $\mathbf{R}^{2}$ pada hasil regresi persamaan pertama < nilai Adjusted $\mathbf{R}^{2}$ pada hasil regresi persamaan kedua, maka variabel yang dihipotesiskan sebagai variabel moderasi dapat digunakan sebagai variabel moderasi.

\section{HASIL DAN PEMBAHASAN}

\section{Pengujian Hipotesis 1}

Hasil penelitian variabel persistensi laba diperoleh nilai signifikansi sebesar 0,785 dengan koefisien regres (beta) sebesar 0,001 sehingga dapat dikatakan bahwa persistesi laba tidak 
berpengaruh terhadap kualitas laba. Dengan demikian hipotesis pertama $\left(\mathrm{H}_{1}\right)$ yang menjelaskan bahwa persistesi laba berpengaruh positif terhadap kualitas laba ditolak.

Persistensi laba tidak berpengaruh terhadap kualitas laba karena dalam menentukan keputusan investasi, investor tidak hanya menilai berdasarkan informasi laba, akan tetapi investor juga menilai informasi lain yang mungkin berpengaruh terhadap investasinya. Persistensi laba yang tinggi belum tentu mendapatkan respon positif dari investor. Laba yang kurang informatif membuat investor cenderung tidak reaktif atas pengumuman laba. Hal yang membuat laba tidak informatif adalah adanya komponen transitory laba yang hanya akan meningkatkan laba pada suatu periode berjalan saja. Penelitian ini sejalan dengan penelitian Marisatusholekha dan Budiono (2015) serta Apriliana (2017) yang menyatakan persistensi laba tidak berpengaruh terhadap kualitas laba.

\section{Pengujian Hipotesis 2}

Hasil penelitian variabel Book Tax Differences diperoleh nilai signifikansi sebesar 0,012 dengan arah koefisien regresi (beta) sebesar -1,781. Tingkat signifikansi variabel Book Tax Differences lebih kecil dari alpha 0,05 sehingga dapat disimpulkan bahwa variabel book tax differences berpengaruh negatif terhadap kualitas laba. Dengan demikian hipotesis kedua $\left(\mathrm{H}_{2}\right)$ yang menjelaskan Book Tax Differences berpengaruh negatif terhadap kualitas laba diterima.

Book tax differences berpengaruh negatif terhadap kualitas laba karena adanya koefisien beban pajak tangguhan yang menunjukkan bahwa penurunan beban pajak tangguhan akan meningkatkan kemungkinan perusahaan untuk melakukan manajemen laba. Book tax differences dapat memicu peluang terjadinya management discretion dan dapat memengaruhi kualitas laba karena terjadinya book tax differences dapat disebabkan oleh adanya tindakan manajemen laba yang dilakukan oleh perusahaan dalam strategi perencanaan perpajakan pada perusahaan, strategi tersebut dilakukan karena adanya perbedaan perlakuan atas pendapatan dan beban menurut akuntansi dan menurut perpajakan. Semakin tinggi book tax differences maka semakin rendah kualitas laba yang dihasilkan karena anggapan bahwa perusahaan tersebut melakukan manajemen laba untuk meminimalisir kerugian. Penelitian ini sejalan dengan penelitian Amelia dan Yudianto (2016) yang menyatakan bahwa book tax differences berpengaruh negatif terhadap kualitas laba.

\section{Pengujian Hipotesis 3}

Hasil penelitian variabel investment opportunity set diperoleh nilai signifikansi sebesar 0,870 dengan arah koefisien regresi (beta) 0,001. Tingkat signifikansi variabel Investment Opportunity Set lebih besar dari alpha 0,05 sehingga dapat disimpulkan bahwa variabel Investment Opportunity Set tidak berpengaruh terhadap Kualitas Laba. Dengan demikian hipotesis ketiga $\left(\mathrm{H}_{3}\right)$ yang menjelaskan bahwa Investment Opportunity Set berpengaruh positif terhadap Kualitas Laba ditolak.

Investor tidak menjadikan Investment opportunity set sebagai pusat perhatian dalam mengambil keputusan investasi karena motivasi investor dalam berinvestasi adalah untuk memperoleh keuntungan jangka pendek bukan untuk jangka panjang. Dalam berinvestasi investor tidak termotivasi untuk memperoleh keuntungan jangka panjang, faktor kesempatan bertumbuh yang dilihat dengan investment opportunity set biasanya diamati oleh investor mempunyai perspektif keuntungan jangka panjang. Penelitian ini sejalan dengan penelitian Darabali dan Saitri (2016) yang menyatakan bahwa investment opportunity set tidak berpengaruh terhadap kualitas laba.

\section{Pengujian Hipotesis 4}

Hasil penelitian variabel Struktur Modal diperoleh nilai signifikansi sebesar 0,001 dengan arah koefisien regresi (beta) 0,084. Tingkat signifikansi variabel Struktur Modal lebih kecil dari alpha 0,05. Sehingga dapat disimpulkan bahwa variabel Struktur Modal berpengaruh positf 
terhadap kualitas laba. Dengan demikian hipotesisi keempat $\left(\mathrm{H}_{4}\right)$ yang menjelaskan bahwa Struktur Modal berpengaruh positif terhadap kualitas laba diterima.

Perusahaan dengan struktur modal yang tinggi menunjukkan bahwa perusahaan tersebut akan semakin dinamis. Perusahaan akan lebih termotivasi untuk terus meningkatkan kinerjanya agar hutang-hutangnya dapat terpenuhi. Perusahan dengan laba yang optimal akan membuat pihak eksternal merespon positif perusahaan tersebut sehingga tidak segan untuk menanamkan modalnya pada perusahaan tersebut. Hasil penelitian ini sejalan dengan penelitian yang dilakukan oleh Dira dan Astika (2014) serta Risdawaty dan Subowo (2014) menyatakan bahwa struktur modal berpengaruh positif sedangkan terhadap kualitas laba. Semakin besar leverage pada perusahaan, maka kualitas laba yang dihasilkan akan semakin tinggi.

\section{Pengujian Hipotesis 5}

Hasil penelitian ini diperoleh nilai nilai signifikansi pada BTD ${ }^{*} \mathrm{KA}$ sebesar 0,001 dengan nilai koefisiensi (beta) sebasar -16.882. Sehingga dapat disimpulkan bahwa Koservatisme akuntansi memperlemah hubungan antara book tax differences dan kualitas laba. Dengan demikian hipotesis kelima $\left(\mathrm{H}_{5}\right)$ yang menjelaskan bahwa Koservatisme akuntansi memperlemah hubungan antara Book tax differences dan kualitas laba diterima.

Pemilihan metode akuntansi yang konservatif dinilai baik untuk menganalisis kualitas laba perusahaan. Metode akuntansi yang konservatif dianggap dapat lebih memperlihatkan informasi laba perusahaan yang lebih berkualitas karena prinsip konservatisme akuntansi mendorong perusahaan untuk tidak terlalu optimis dalam memprediksi laba dimasa yang akan datang. Metode konservatisme akuntansi akan lebih membantu book tax differences memiliki kualitas laba yang lebih baik. Namun, sikap pesimistik manajemen dalam pelaporan laba dapat berakibat anggapan kurang baik terhadap kinerja manajemen dalam mengelola perusahaan karena tidak menghasilkan laba yang sesuai target (Soraya dan Harto, 2014). Hasil Penelitian ini sejalan dengan penelitian Sarra (2017) yang menyatakan bahwa manajemen menggunakan prinsip konservatisme akuntansi bukan dengan maksud untuk mengurangi besar pajak tetapi merupakan kecenderungan yang dimiliki oleh manajemen untuk mengakui laba lebih rendah.

\section{KESIMPULAN}

Penelitian ini bertujuan untuk menguji dan mendapatkan bukti empiris mengenai pengaruh persistensi laba, book tax differences, investment oppotunity set, dan struktur modal terhadap kualitas laba dengan konservatisme akuntansi sebagai variabel moderasi. Sampel yang digunakan dalam penelitian ini adalah sampel dari perusahaan jasa yang terdaftar di Bursa Efek Indonesia pada periode 2015-2017. Berdasarkan hasil penelitian dan pembahasan, maka dapat disimpulkan bahwa persistensi laba tidak berpengaruh tehadap kualitas laba pada perusahaan jasa tahun 20152017. Book tax differences berpengaruh negatif tehadap kualitas laba pada perusahaan jasa tahun 2015-2017. Investment opportunity set tidak berpengaruh tehadap kualitas laba pada perusahaan jasa tahun 2015-2017. Struktur modal berpengaruh positif tehadap kualitas laba pada perusahaan jasa tahun 2015-2017. Konservatisme akuntansi dapat memoderasi hubungan antara Book tax differences dan kualitas laba pada perusahaan jasa tahun 2015-2017.

Berdasarkan hasil penelitian yang telah dilakukan, terdapat beberapa saran yang dapat peneliti berikan untuk penelitian selanjutnya dapat menambah variabel lain dalam penelitian. Penelitian selanjutnya dapat mengembangkan jenis sampel yang berbeda. Penelitian selanjutnya diharapkan untuk memperpanjang periode penelitian agar dapat menggambarkan kondisi perusahaan yang sebenarnya. Penelitian selanjutnya disarankan dapat mencari variabel pemoderasi lain untuk mendapatkan hasil yang berbeda. Menggunakan proksi lain dalam pengukuran Book tax differences dan persistensi laba. 


\section{DAFTAR PUSTAKA}

Ambarwati, S. (2008). Earning Response Coefficient. Jurnal Akuntansi, 7(2).

Amelia, N., \& Yudianto, I. (2016). Pengaruh Book Taax Differences Terhadap Kualitas Laba dengan Manejemen Laba Sebagai Variabel Intervening. Jurnal Akuntansi dan Keuangan, $16(1)$.

Anjelica, K., \& Prasetyawan, A. F. (2014). Pengauh Profitabilitas, Umur Peusahaan, Ukuran Perusahaan, Kualitas Audit dan Struktur Modal terhadap Kualitas Laba. Ultima Accounting, 6(1).

Apriliana, V. (2017). Pengaruh Book Tax Differences dan Persistensi Laba Terhadap Kualitas Laba. ASSETS.

Basu, S. (2009). Conservatism Research: Historical Development and Future Prospect. China Journal of Accounting, 2(1).

Chowdhury , A., \& Chowdhury, S. (2010). Impact of Capital Structure on Firm's Value: Evidence from Bangladesh. Business and Economis Horizons, 3(3), 111-122.

Darabali, P., \& Saitri, P. (2016). Analisis Faktor-Faktor yang Memengaruhi Kualitas aba pada Perusahaan Manufaktur di Bursa Efek Indonesia tahun 2020-2013. Jurnal Riset Akuntansi.

Dewi, N. P., \& Putri, I. A. (2015). Pengaruh Book-Tax Difference, Arus Kas Operasi, Arus Kas Akrual, Dan Ukuran Perusahaan. E-Jurnal Akuntansi Universitas Udayana.

Dira, K. P., \& Astika, I. P. (2014). Pengaruh Struktur Modal, Likuiditas, Pertumbuhan Laba dan Ukuran Perusahaan pada Kualitas Laba. E-Jurnal Akuntansi Universitas Udayana, 7(1), 64-78.

Djamaluddin, S.H.T, Wulandari, \& Rahmawati. (2008). Analisis Perbedaan Antara Laba Akuntansi dan Laba Fiskal terhadap Persistensi Laba Akrual dan Aliran Kas pada Perusahaan Perbankan yang terdaftar di Bursa Efek Jakarta. Jurnal Riset Akuntansi, 11, 53-74.

En, T. K. (2017). Konservatisme Akuntansi Diantara Book Tax Differences, Pengungkapan Corporate Goverrnance dan Kualitas Laba. Jurnal Akuntansi Manajerial, 2(1).

Ghozali, I. (2011). Aplikasi Analisis Multivariate dengan Program IBM SPSS 19. Semarang: Badan Penerbit Universitas Diponegoro.

Hanlon, M. (2005). The Persistence of Earnings, Accruals and Cash Flow When Firms Hve Large Book Tax Differences. The Acccounting Review 80 March, 137-166.

Malahayati, R., Arfan, M., \& Basri, H. (2015). Pengaruh Ukuran Perusahaan,dan Financial Leverage Terhadap Persistensi Laba dan Dampaknya Terhadap Kualitas Laba. Jurnal Manajer Akuntansi, 4(4).

Marisatusholekha, \& Budiono, E. (2015). Pengaruh Komisaris Independen, Reputasi KAP, Persistensi Lba dan Struktur Modal Terhadap Kualitas Laba. Bina Ekonomi.

Midiastuty, P., Suranta, E., \& Dita Lidya Ofprama. (2017). Pengaruh Book Tax Differences terhadap Relevansi Nilai Informasi Laba. SIMPOSIUM NASIONAL AKUNTANSI XX JEMBER.

Mulyani, S., Asyik, N. F., \& Andayani. (2007). Faktor-Faktor yang Memengaruhi Earnings Response Coeficient pada Perusahaan yang Terdaftar di Burrsa Efek Jakarta. Jurnal Akuntansi dan Auditing Indonesia.

Nazaruddin, I., \& Basuki, A. T. (2017). Analisis Statistik Dengan SPSS. Yogyakarta: Danisa Media.

Penman, S. H., \& Zhang, X. J. (2002). Accounting Conservatism, the Quality of Earnings and Stock Returns. The Accounting Review, 77(2).

Persada, A., \& Martani, D. (2010). Analisis Faktor yang Memengaruhi Book Tax Gap dan Pengaruhnya terhadap Persistensi Laba. Jurnal Akuntansi dan Keuangan Indonesia, 7(2).

Rachmawati, A., \& Triatmoko , H. (2007). Analisis Faktor-faktor Yang Memengaruhi Kualitas Laba dan Nilai Perusahaan. SNA $X$. 
Risdawaty, I., \& Subowo. (2015). Pengaruh Struktur Modal, Ukuran Perusahaan, Asimetri Informasi dan Profitabilitas terhadap Kualitas Laba. Jurnal Dinamika Akuntansi, 7(2).

Sarra, H. D. (2017). Pengaruh Konvesrsatisme Akuntans, Komite Audit dan Dewan Komisaris Independen terhadap Pengindaran Pajak. Competitive, 1(1).

Scott, W. R. (2006). Financial Accounting Theory (Vol. fourth edition). United States of America: Pearson Pentice Hall.

Situmorang, C. V. (2017). Analisis Faktor-Faktor yang Mempengaruhi Kualitas Laba. Jurnal Kewirausahaan, 3(2), 50-58.

Spence, M. (2009). Job Market Signling. The Quarterly Journal of Economics, 87(3).

Suandy, E. (2011). Hukum Pajak (Vol. Edisi 5). Jakarta: Salemba Empat.

Sugiarto, Lesia, B., \& Siagian, D. (207). Faktor-faktor yang Memengaruhi Kualitas Laba pada Peusahaan Manufaktur di BEJ. Jurnal Akuntabilitas, 6(2), 142-149.

Sunyoto, D. (2013). Metodologi Penelitian Akuntansi. Bandung: PT. Refika Aditama.

Tampubolon, T. M., \& Kartikaningdyah, E. (2016). Pengaruh Karakteristik Perusahaan terhadap Book Tax Differences. Junal Akuntansi, Ekonomi dan Manajemen Bisnis, 4(1), 52-59.

Tang, T. (2006). Book Tax Differences, A proxy for Earnings Maagement and Tax Management Emprical Evidence from china. Working Paper.

Warianto, P., \& Rusiti, C. (2014). Pengaruh Ukuran Perusahaan, Struktur Modal, Likuiditas dan Investment Opportunity Set (IOS) Terhadap Kualitas Laba Pada Perusahaan Manufaktur yang Tedaftar di BEI. MODUS, 26(1), 19-32.

Wijayanti, H. T. (2006). Analsis Pengaruh Perbedaan antara Laba Akuntansi dan Laba Fiskal Terhadap Persistensi Laba, Akrual dan Arus Kas. Simposium Nasional Akuntansi IX, Padang.

Yulianti. (2005). Kemampuan Beban Pajak Tangguhan dalam Mendeteksi Manajemen Laba. Simposium Nasional Akuntansi VII (Denpasar). 